\title{
Premodern Debasement: A Messy Affair
}

\author{
Oliver Volckart \\ London School of Economics
}




\title{
LONDON SCHOOL OF ECONOMICS AND POLITICAL SCIENCE DEPARTMENT OF ECONOMIC HISTORY WORKING PAPERS \\ NO. 270 - DECEMBER 2017
}

\author{
Premodern Debasement: \\ A Messy Affair \\ Oliver Volckart \\ London School of Economics
}

\begin{abstract}
The paper argues that in premodern Europe, the practice of debasement was far more 'messy' than research has generally recognised. First, high information costs often prevented the effective control of mint officials who could exploit their resulting autonomy in order to debase coins on their own account. Second, these costs made it impossible to monitor markets closely enough to enforce regulations. Attempts by governments to debase coins by increasing their nominal value therefore 'worked' only if they conformed to the market rates of these coins. Finally, high information costs prevented the creation of closed areas where the domestic currency enjoyed a monopoly. The resulting trade in coinage created incentives for governments to issue inferior copies of their neighbour's coins a practice that had the same consequences as a debasement - and forced the affected governments to follow suit by debasing their own coinage, too.
\end{abstract}

Keywords: Monetary policies, debasements, monitoring costs, currency markets, late middle ages, early modern period.

JEL Classification Numbers: N13, N23, N43 


\section{Premodern Debasement: A Messy Affair}

Contents

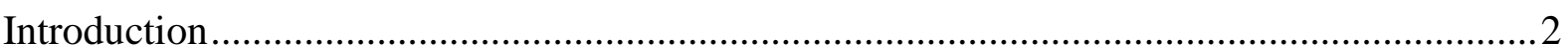

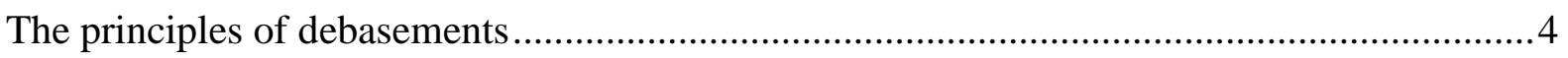

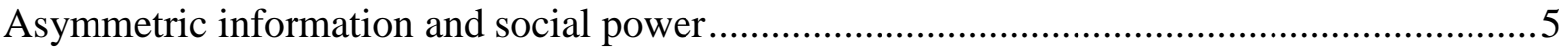

Information costs, political capacity and monetary policies............................................. 9

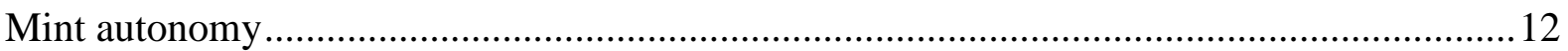

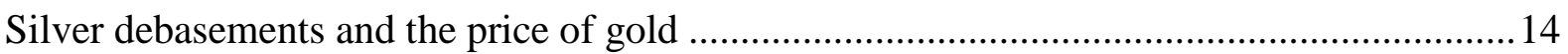

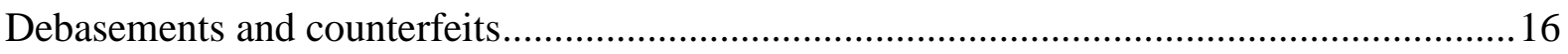

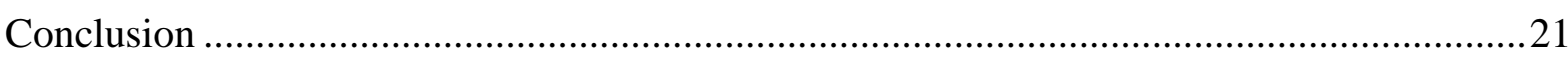

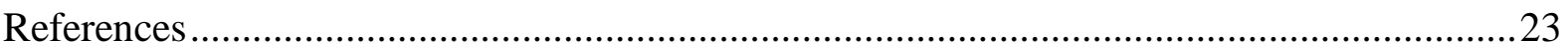




\section{Introduction}

On New Year's Eve 1519, Albert of Brandenburg (1511-68), Grandmaster of the Teutonic Order that had ruled Prussia since the thirteenth century, began a war against the neighbouring kingdom of Poland. In order to finance this undertaking, in particular to pay the mercenaries he engaged in Germany and Denmark, he instructed his mint to increase its output. The mint master and moneyers obliged. Churches were stripped of their ornament and the subsidies sent by Muscovy and Livonia were directly handed over to the mint to be melted and re-issued as Prussian coins (Volckart 1996: 242). However, after the Holy Roman Emperor Charles V (1519-56) had mediated an armistice, trouble began. A contemporary annalist noted that when the lansquenets were disbanded and

'moved off on the Tuesday after Misericordia Domini [16 April 1521, OV], there was much scolding and cursing because no-one wanted to accept the coins with which they had been paid. They therefore took their pay with them and were ferried from Tolkemit across the lagoon to the Vistula Spit, and took their way from there across the mouth of the Vistula towards Pomerania. And from Danzig they were provisioned with beer and bread and other things. So the Danzigers received a great many of these coins, too; moreover, many bought them for half their value, believing to make a good deal. However, once the intrinsic value of this money had been determined, it was soon despised throughout the whole country' (Meckelburg 1865: 158 f.).

The initial acceptance of a ruler's new money, followed by disillusionment and rejection, was a common pattern under conditions such as those the Prussian annalist described. The episode thus illustrates a typical consequence of a widely practiced type of monetary policies in premodern Europe: debasement, that is, in its widest definition, an increase in the ratio between the nominal and intrinsic value of money. In the Prussian case, the ruler ordered the bullion content of his coinage to be reduced. In addition, the mint resorted to labour saving strategies, issuing square coins that were quicker to cut from the metal sheets than properly rounded ones, and focussing on minting large denominations. In nominal terms, this allowed the production of huge sums of money while requiring relatively less labour than the smaller round coins that had been common until then (Volckart 1996: 243).

Reducing the bullion content of coins relative to their nominal value - i.e. replacing part of the pure silver or gold they contained with a base metal such as copper - was only one of several ways of how a debasement might be carried out. There were two other options. A 
ruler or government could reduce the weight of the coins that his mint issued while maintaining both the composition of the alloy of which they were made - i.e. the proportion of bullion to base metal - and their official value. Alternatively, both the weight and the fineness of the coins could be left unchanged; what the minting authority did was increase their official value. This third option was particularly tempting because premodern coins were rarely marked with their 'face' value. Thus, the French gros tournois, introduced as a 12-deniers piece under Louis IX (1214-70), did not show the numeral 'XII', though its design did contain twelve fleurs de lis, which presumably were intended to indicate its nominal value (cf. Blanchet and Dieudonné 1916: 227). By contrast, nothing in the design of the English groat first minted at the time of Edward I (1272-1307) betrayed that it was to circulate as a 4-pence piece.

The monetary toolkit of premodern rulers and governments contained few instruments apart from debasements (and their rarely used opposite, i.e. reinforcements). This did not fundamentally change before the end of the early modern age when central banks issuing paper money became common throughout Europe. Thus, in the mid-eighteenth century, Frederick II of Prussia (1740-86) debased his coinage in much the same way and for the same reasons as his distant relative, Albert of Brandenburg, had done two and a half centuries before (with the seignorage covering about one-third of his expenditure during the SevenYears War, Koser 1900: 359), or, for that matter, as the Dauphin, later Charles VII of France (1429-61) did in the early fifteenth century (who increased his revenues by a factor of six by debasing his coinage, Sussman 1993: $66 \mathrm{f}$.). In monetary politics, the traditional dividing line between the Middle Ages and early modernity in about 1500 is thus even less appropriate than in other fields of history (cf. Scott 2015: 19 ff.). If a line needs to be drawn, it is in the late thirteenth and fourteenth centuries when European polities began issuing complex currencies composed of multiple denominations and based on different precious metals. This is also a question of research practicalities. As chemical analyses of surviving coins have shown, debasements were frequent in the earlier Middle Ages, i.e. between roughly the sixth and the thirteenth centuries (Metcalf and Merrick 1967). However, in most places so few written sources have survived from that time that we are on shaky ground when we want to examine such policies. In many respects, therefore, the period from the fourteenth to the middle of the eighteenth century appears as a historical unit not only because monetary policies remained essentially the same, but also because we are in a position to analyse them. 
Until not so long ago debasements remained poorly understood. A high-profile paper by three eminent economists (Rolnick, Velde, and Weber 1996) even talked of a 'debasement puzzle'. In fact, as shown below, there is no such puzzle; debasements were at least in principle fairly straightforward measures. A number of recent articles have done much to systematically explain how and why they occurred. Notably, Chilosi and Volckart (2017) present a statistical analysis of the relative importance of the different motives and aims pursued by authorities who debased their coinage. Summarising core insights from a lifetime of research, Munro (2015) used one of his last papers to set out the technology and economics of debasements in the late Middle Ages and at the beginning of the early modern age. In view of these advances in recent research, the present chapter aims at presenting debasements in the wider context of contemporary conditions in society, the economy and specifically monetary policies. Its hypothesis is that while the principles underlying debasements are clear enough, the practice of debasement deviated in many places from the picture drawn by prior research. The chapter argues that this was mainly the case because of high information costs, which not only created conditions that occasionally left authorities little choice but to debase their currency, but which also prevented them from effectively implementing such measures.

\section{The principles of debasement}

In order to explain how debasements worked, it is useful briefly to recapitulate the mechanisms of the money supply in the period considered here. The following sketch summarises the standard analysis of the process (cf. Gould 1970: $7 \mathrm{ff}$., Rolnick, Velde, and Weber 1996: 790, Munro 2015: 19 ff.). The fundamental assumption is that only metal sold voluntarily to the mint would be minted. In order to do so, the mint would offer a price for any given quantity of gold or silver it wished to buy; this was the mint price. The total nominal value of the coins made from this quantity of metal was the mint equivalent. The mint equivalent was always higher than the mint price, with the difference used to cover the rest of the production costs. After all, the mint also needed to buy base metal to produce the alloys from which the coins were struck and firewood or charcoal to melt the metal. Moreover, the upkeep of the mint buildings involved costs, the tools needed to be manufactured or purchased and the workmen to be paid. Last but not least the leading official, i.e. the mint master, needed an income. This usually consisted of what was left of the newly minted money after he had paid all the other costs and the seignorage: the share due to the political authority on whose behalf he was minting. 
One implication of the mint equivalent being higher than the mint price was that the nominal value of a coin regularly exceeded its intrinsic value. Put differently, coins normally circulated at a value that was roughly equal to the sum of their production costs and seignorage (cf. Sargent and Velde 2002: 18 f.). The difference between the intrinsic and nominal values had itself a further implication that was crucially important for how debasement worked. Regardless of whether a political authority chose to reduce the weight of a coin, to reduce the proportion of pure precious metal it contained, or to increase in its official value, the measure always entailed a growth of the mint equivalent. This, in turn, allowed the authority to increase its seignorage and the mint to offer a higher mint price in order to attract more bullion. Hence, debasements allowed both minting volumes and revenues from seignorage to grow. To give an example, when in the early 1540s Henry VIII (1509-47) debased the English silver coinage by reducing the purity of the metal, the mint in the Tower of London was able to pay merchants a higher nominal price for the silver they supplied. As a consequence, the output of the mint increased by a factor of nine between 1542 and 1546 (Gould 1970: 38). However, the increase in the mint price of silver meant that in relative terms, gold became cheaper. Therefore, in order to prevent merchants from buying up English gold coins and exporting them, gold had to be debased, too. This is what happened, though the purity of the gold coins remained largely unchanged: Rather, their nominal values were increased (Gould 1970: 48 f.). This episode and similar events in particular in the Burgundian Netherlands of the late fourteenth and fifteenth centuries persuaded Munro (2015: $16 \mathrm{f}$.) that debasing silver usually forced a government to debase gold, too.

\section{Asymmetric information and social power}

The 'debasement puzzle' identified by Rolnick, Velde and Weber (1996) concerned the causes of the increase in mint output after a debasement had been implemented. They argued that as bullion merchants were aware of the change in the ratio between nominal and intrinsic value which the debasement involved, there would have been no incentive to supply the mint with additional gold and silver that could then be used to produce a higher number of coins. It is indeed plausible that at least some merchants who sold bullion to mints knew about the fine silver or gold content of the coins they received in return. Still, the perceived puzzle has a fairly straightforward solution. 
In order for a debasement to 'work' in the way described above, specifically in order for mints to be able to increase their output after a debasement, the wider public - that is, not the bullion merchants - had to keep focussing on the nominal value of coins rather than on their intrinsic value at least for some time after the measure had been taken. In other words, when a ruler or government debased the coinage, bullion merchants would keep supplying the mint with raw metals as long as they expected to find consumers willing to use coins 'by tale' rather than 'by weight'. For this to happen, at least one condition was necessary: Either it had to be possible to pass off debased money as unadulterated, or to force consumers who knew of the debasement to accept the coins at a value higher than that their bullion content justified. The first condition seems frequently to have been met. For example, in Prussia in 1521, the lansquenets initially seem to have assumed that the pay they received consisted of relatively 'good' coins, i.e. even if they expected some debasement, they were not aware of its extent. The issue had two aspects. First, for consumers such as them, it was hard to determine what the legal standard of their coins actually was. Governments may have published mint prices, but most kept information concerning e.g. mint equivalents closely guarded secrets (Redish 2000: 28). Even where this information was published - as for example in the Holy Roman Empire where currency competition was intensive and governments seem to have hoped that the public would help weed out underweight coins - it was accessible only to those able to read and understand legal texts (Volckart 2017a: LIXX f.).

Literacy - or the lack of it - therefore played an important role where debasements are concerned. To give an idea of the order of magnitude about which we are talking here: it has been estimated that over the sixteenth century, the share of the population able to read and understand complex texts such as for example currency laws grew to more than 5 per cent in the German-speaking parts of the Holy Roman Empire (Engelsing 1973: 32). Using the number of new book editions as a lead indicator, this share must have about tripled by the mid-eighteenth century (cf. Buringh and van Zanden 2009: 421). There were obviously wide social and regional variations in literacy which moreover was always higher among men than women (Houston 2014: 142-162). Still, for most of the period discussed here and most parts of Europe, the vast majority of consumers were illiterate in the sense of being unable to read and understand monetary ordinances, if these were published at all. It is therefore fair to assume that they had no idea of how much bullion their money was supposed to contain, and lacked any standard against which to measure its intrinsic value. 
In principle, of course, knowing about the legal standard of the coinage was not necessary if one was able to determine whether the intrinsic value of the coins one handled had been changed, i.e. if one could compare the bullion content of new coins to that of older ones of the same official value. However, doing this was costly and time consuming. Most importantly, it required knowledge and tools that only a small number of experts had. To check the weight one needed a set of precision scales and weights, to check the purity at least a touchstone and a set of touch needles. The needles left lines on the touchstone whose colours one could compare with that left by the coin one was testing: A matching colour signalled a matching degree of purity. This method allowed an accuracy of $\pm 2-3$ per cent (Redish 2000: 22); more precise analyses required melting the coin, separating the components of its alloy and determining their relative weight. ${ }^{1}$ To do this, one needed metallurgical tools and in-depth knowledge and skills possessed by a very small share of the population: some merchants used to handling precious metal, professional money changers and of course mint masters. The majority of consumers - mostly illiterate peasants or craftsmen, small hucksters, local traders and certainly the lansquenets Grandmaster Albert of Brandenburg employed - were in no position to check the intrinsic value of their coins.

Under these circumstances, debasements worked because governments could be confident that few people would immediately become aware of a reduction in the weight of a coin or in its bullion content. At some point, of course, the news would spread: the informational asymmetry would be eroded. In Prussia, this took some time. It was a neighbouring ruler, the bishop of Warmia, who first became suspicious and ordered a test of the money early in 1521. The result was so appalling that he notified the council of Königsberg (the Grandmaster's residence-city), whose members immediately lodged a complaint with their lord: 'They were truly terribly shocked; they neither would nor could reveal this to their commune, as your grace can easily imagine what moaning and wailing would follow' (Meyer 1912: 596). The episode illustrates how different groups in society might become aware of debasements at different times: Merchants and urban councils first, the other members of urban communes later, and crucially, the group whom the government was most interested in 'fooling' - in this case the lansquenets - last. From the perspective of the Grandmaster of the Teutonic Order, his policy was a success.

1 The method is described by Fachs (1678: 47-51). 
There was another condition that could contribute to the success of debasements: the hierarchical structure of premodern society (Münch 1996: $65 \mathrm{ff}$.). The term hierarchy is to be taken literally. Almost any member of society was regularly confronted with someone else who was not just his or her superior in some poorly defined social sense, but who enjoyed more privileges, freedoms and often the right to exert some form of political authority. Over time, the attempts of monarchs to establish monopolies of force and to level legal distinctions among their subjects caused an erosion of this kind of hierarchy - a process that began earlier and was quicker in some countries (e.g. England and the Dutch Republic) than in others (for example in Spain, France, Germany or Poland) (van Zanden and Prak 2006, Hettling 2015: 124). However, over much of Europe and most of the late Middle Ages and the early modern period, social hierarchies remained strong.

Even where consumers already knew about a debasement, they were therefore frequently in no position to resist their betters when these used debased money to pay wages or goods (Rössner 2012: 585 f., 2014). Hence, informational asymmetries between producers of money and consumers were no necessary condition for debasements to be feasible. Strong social hierarchies might be sufficient. There is evidence that consumers were at least occasionally and to some extent aware of the quality of the coins with which they were paid. Thus, in mid-fifteenth-century Freiberg in Saxony, an important mining centre where metallurgical information was probably easy to come by, labourers repeatedly protested against the payment of wages in debased coin (Laube 1976: 208 f.). According to Rössner (2012: $491 \mathrm{ff}$.), being forced to accept debased money contributed crucially to the decision of peasants in Upper Germany to revolt in 1525, and indeed, complaints about the circulation of debased coins were commonplace in the early sixteenth century. Some consumers, though, did not rebel but retaliated in more subtle ways. For example, in late fifteenth- and early sixteenth-century Nuremberg, coins of doubtful value appeared over proportionally often in the churches' collection boxes (Groebner 1993: 48).

Recent research thus has established the principles underlying debasements and the conditions that allowed them to 'work' from the ruler's or government's perspective: It has solved the 'puzzle'. However, it is striking that this research has so far focused on a relatively small number of examples mainly derived from England, France, Burgundy and Italy. As will be shown below, this is problematic because these were not only economically the most advanced parts of premodern Europe, but also politically the best organised. Late medieval Burgundy and even more Tudor England stand out as polities where governmental decisions 
were implemented more effectively than almost anywhere else in Europe at the time. It is the core hypothesis of the present chapter that in most parts of the continent debasements - and monetary policies in general - were far more 'messy' affairs than in those countries on which research has tended to focus. In order to explain why this was the case, it is necessary to extend the scope of the argument.

\section{Information costs, political capacity and monetary policies}

One crucial factor has already been mentioned: information. When implementing debasements, rulers and governments usually benefited from the poor state of information of the consumers using debased money. The information needed to make informed decisions about which coins to accept and which to reject, be it at a mint or on a market place, was difficult and costly to come by. However, while in this respect authorities benefited from high information costs, there were other ways in which the same costs affected them. Not only was literacy weak, with many branches of administration using written records sparingly; information also spread slowly. With the exception of rare and not particularly reliable carrier pigeons, nothing moved more quickly than a horse could run. Thus, while twelfth-century express messengers could cover up to 40 miles per day, improvements in infrastructure meant that by the sixteenth century distances of up to 60 miles were reached (Denecke 1990: 217). Regular postal services - introduced first in the Empire at the end of the fifteenth century improved information flows further. In 1500, the mail needed thirty days to cover the 400 miles between Hamburg and Augsburg, in 1615 eleven days and in 1800 five days (Behringer 2005: 48). Still, while the transmission of information became more reliable, its speed did not increase as much as the travel times of mail riders suggest. Even at the end of the eighteenth century, their average speed was only about 25 per cent higher than that achieved by express messengers 300 years before.

Conditions such as these had several implications for monetary policies. For one thing, high information costs made implementing decisions difficult. Again, the problem had several aspects. Thus, on occasion rulers even found it hard to learn what was going on in their own mints. For example, in 1527 the councillors of Albert of Brandenburg - who, after his failure in war, had turned the state of the Teutonic Order into a secular duchy and a Polish fief found it necessary to interrogate the mint master, the leading official of the Königsberg mint. Accounts the master might have kept obviously did not exist. The result of the interview was shocking. Not only had the duke failed to engage a warden of the mint, that is, a supervisor 
responsible for testing newly minted money. The mint master had also never transferred any seignorage to the ducal treasurer, who himself admitted that he could not remember whether the seignorage had ever even been mentioned between the two of them. When finally asked on whose authority he was minting, the master declared 'he hoped that if he had minted [...], this would not be to my gracious lord's [the duke's, OV] displeasure [...]. He had used his own silver and the residual left in the crucibles, and had only minted to meet his personal expenses' (Volckart 1996: 409 f.). In other words, the mint master acted without any supervision, running the mint like a private enterprise where he produced any amount of money he felt he needed. Nothing suggests that conditions like these were unusual. In late medieval and early modern Europe there were many hundreds of small, workshop-like mints, in the Holy Roman Empire alone c. 500 in about the year 1500 (Sprenger 2002: 81). Most of these operated on behalf of small towns, lords or abbeys who lacked the resources needed to cover the high costs of supervising officials. Moreover, rulers in many parts of Europe farmed out their mints - often for years at a time - which implied a far-reaching loss of control (Spufford 1988: 17).

High information costs also affected the ability of a ruler or government to enforce monetary regulations vis-a-vis the public. As the vast majority of consumers were unable to read and understand handwritten or printed edicts, such regulations had to be announced by word of mouth - a process prone to giving rise to all kinds of misunderstandings. Another Prussian example shows how officials tried to deal with this. A few years after the scandal about the Königsberg mint, the duchy of Prussia entered a currency union with Poland. When the new money was introduced, it proved - as usual (Miskimin 1985/89: 148) - impossible to withdraw the old coins from circulation; they had to be allowed to continue to circulate at fixed rates expressed in new money. This gave rise to a large amount of confusion. When taken to task by the ducal councillors, the mayor of Königsberg defended himself:

'What had happened [...] at the start of the annual fair was that such a crowd of common people, who had come in large numbers to visit the fair, had appeared and inquired about the coinage that he could in no way answer all their questions and correct their mistakes. However, he had ordered the town servants to walk up and down the streets to inform people how to give and take the coins in accordance with the edict [about the new coinage, OV]. But even if there had been fifty more of them, they would not have been enough, even if each had answered a hundred and more people a day; my gracious lord's councillors might imagine when he himself might rest his mouth, and if things continued 
like this he would rather be a swineherd than mayor, and gave notice of much other hardship and annoyances he had suffered because of this' (Volckart 1996: 415).

On top of the high costs of informing the public about monetary policy, a second problem appeared: Once consumers (or at least some of them) had learned about a political decision, premodern governments were generally unable to monitor markets closely enough to determine whether or to what extent their regulations were observed. This is one of the factors that brought down Charles V's project to establish a common currency valid through the whole Holy Roman Empire in the years between 1551 and 1556. Like in the Prussian case a few decades earlier, the old money was supposed to continue to circulate next to the new Imperial currency, and at fixed rates expressed in new money. To give consumers an incentive to sell old coins to the mints that were to melt and re-issue them as new Imperial money, old coins were officially undervalued. Most importantly, the value of Saxon talers in new coins was set below their intrinsic value. Talers, however, were hugely popular - so popular, in fact, that in the northern parts of the Empire they circulated at a premium of about 10 per cent. Charles V's idea that it might be possible to monitor thousands of markets so closely that consumers were forced either to use talers at their official rate or to sell them to a mint was delusional (Volckart 2017b: 773 f.). Nothing like that was remotely possible: Again, high information costs precluded it.

In addition to the difficulties of informing the public about monetary policies and monitoring markets to make sure that regulations were observed, a further problem appeared. Premodern authorities were generally unable to effectively control the borders of their territories. In fact, in most of Europe proper external custom borders did not develop before the eighteenth century, with Bavaria creating them in 1765 and Austria ten years later (Dipper 1991: 176). Before, trade was taxed where it was cheap to monitor: at river crossings, mountain passes or city gates. In consequence, it was neither possible to hinder the export of domestic coins, nor to prevent 'foreigners' from importing their money and spending it. A survey of coins circulating in the Empire made in preparation of Charles V's currency union project found that 97 of the 187 types of gold and 37 of the 134 types of silver coins had been minted abroad (Volckart 2017a: $318 \mathrm{ff}$.). The issue of the parallel circulation of several currencies seems to have been particularly acute in Germany, where consumers used French, Dutch, Danish, British and American coins in day-to-day transactions as late as the second half of the nineteenth century (Helfferich 1900: 188 f.). However, it was by no means restricted to the Holy Roman Empire. In France in 1640, for example, the crown ordered approximately 
45 million livres tournois worth of foreign gold to be re-minted into French coins; according to modern estimates, this was about 20 per cent of the total quantity of money (Glassman and Redish 1985: $44 \mathrm{f}$.). The quantity of foreign silver that continued in circulation is not known.

Conditions such as those described above did not exist everywhere and at all times to the same extent. With the fall of information costs in the course of the early modern period, polities became more effective. Moreover, island governments always found it cheaper to monitor cross-border traffic and began doing so already in the Middle Ages. Thus, by the end of the thirteenth century, merchants visiting England had to declare what foreign money they brought with them and had to exchange it at politically determined rates for English coins; likewise, the export of domestic money was prohibited. There seems to have been a concerted attempt to enforce these rules, but even English consumers used foreign coins. Venetian soldini, for example, circulated as 'galley halfpennies' (Prestwich 1979: 471, Spufford 1963, Daubney 2009). Thus, in most places and for most of the period here considered, governmental ordinances that ordered all foreign coins (and imported precious metal) to be surrendered to the mint to be converted into domestic money were rarely more worth than the paper on which they were published (cf. Munro 2015: $17 \mathrm{f}$.).

\section{Mint autonomy}

While there is some evidence that, occasionally, premodern rulers tried to influence the composition of the coinage issued by their mints, ${ }^{2}$ it was often up to the leading officials to decide which type of coins to strike - the more so, of course, if these officials were as poorly supervised as the mint master of the former Grandmaster of the Teutonic Order in 1527. What this implied for the policies practiced by the mint was described in 1532 by the former monk and metal expert Burkhard Waldis, who wrote a monetary memorandum for the master of the remaining possessions of the Teutonic Knights in Livonia. Waldis argued that if they [i.e. the mint masters, OV] may mint more than just one type of coin, they mint that one most which allows them to make the largest profit' (Arbusow 1910: 799). That the production of different denominations allowed profits of varying size was one of the core problems of premodern currency systems. It was primarily caused by the share of labour costs in the total

2 This was sometimes contractually agreed between rulers and their mint officials. Thus, the contract between Duke Bogislaw X of Pomerania and his mint masters Hermen Mese and Johann Hunde concluded in 1500 determined that they should turn no more than 100 marks (i.e. c. 23 kilograms) of pure silver into 4-penny and penny-pieces, respectively (Klempin 1859: 585 f.). 
production costs of the coinage. In late medieval England, for example, the labour costs involved in producing a farthing, i.e. a quarter penny, were about the same as those that had to be spent in producing a groat, whose value was four pence. As a groat contained exactly 16 times as much pure silver as a farthing, in nominal terms it was possible to produce 16 times more money when the mint issued groats while spending largely the same amount on labour costs. As a consequence, late medieval England suffered from a chronic undersupply of small change. Most polities tried to compensate for the higher share of labour costs involved in the production of small coins by reducing the share of precious metal they contained. In this way, small change became token money that was the more overvalued relative to its intrinsic value, the smaller its nominal value was. The problem was that rulers or governments who chose this solution walked a tightrope. If they did not reduce the share of bullion in the small coins far enough, there would still be incentives to focus on the production of large coins; if they reduced it too far, the mint would issue small change only. This happened for example in early fifteenth century Prussia, where pennies were strongly overvalued relative to shillings. The result was that the country was flooded with small change (Volckart 1996: $90 \mathrm{ff}$.).

Developments in the Holy Roman Empire of the late sixteenth and early seventeenth century show which problems the ineffective supervision of mints by their rulers could cause in this context. One of the issues that Charles V's attempt to create a common Imperial currency in 1551 had thrown up was that small change (defined as all coins below a value of 6 kreuzers) was overvalued too strongly. It was therefore more attractive to mint smaller than larger coins. Moneyers rapidly took advantage of these incentives, occasioning frequent complaints throughout the 1550s (Volckart 2017a: 405, 410). ${ }^{3}$ Accordingly, the Augsburg Imperial Diet of 1559, which reformed Charles' currency, explicitly demanded that small coins should contain so much silver that mints would have no reason to focus on issuing them to the detriment of larger denominations (Leeb 1999: 1376). However, the new Imperial currency law published later that year again missed the mark (cf. Fig. 1 below). This time small change contained too much bullion; producing it cost-effectively was now impossible. As a result, while law-abiding princes such as the Elector of Saxony did not issue any small coins in the decades thereafter, many poorly supervised mints debased them illegally (Wuttke 1897: 248 f.). In particular mints that the authorities had farmed out to private entrepreneurs, who acted without any supervision at all - so called 'Heckenmünzen', literally, mints hidden behind a 
hedge -, were notorious in contributing to the oversupply of debased small change (Schneider 1995: 156 f.). This was the main factor that brought the Imperial currency - which in other respects was well-designed and innovative - into disrepute (Volckart 2017a: LXXIII).

Fig. 1: Overvaluation of small change in the Holy Roman Empire, 1551 and $1559^{4}$

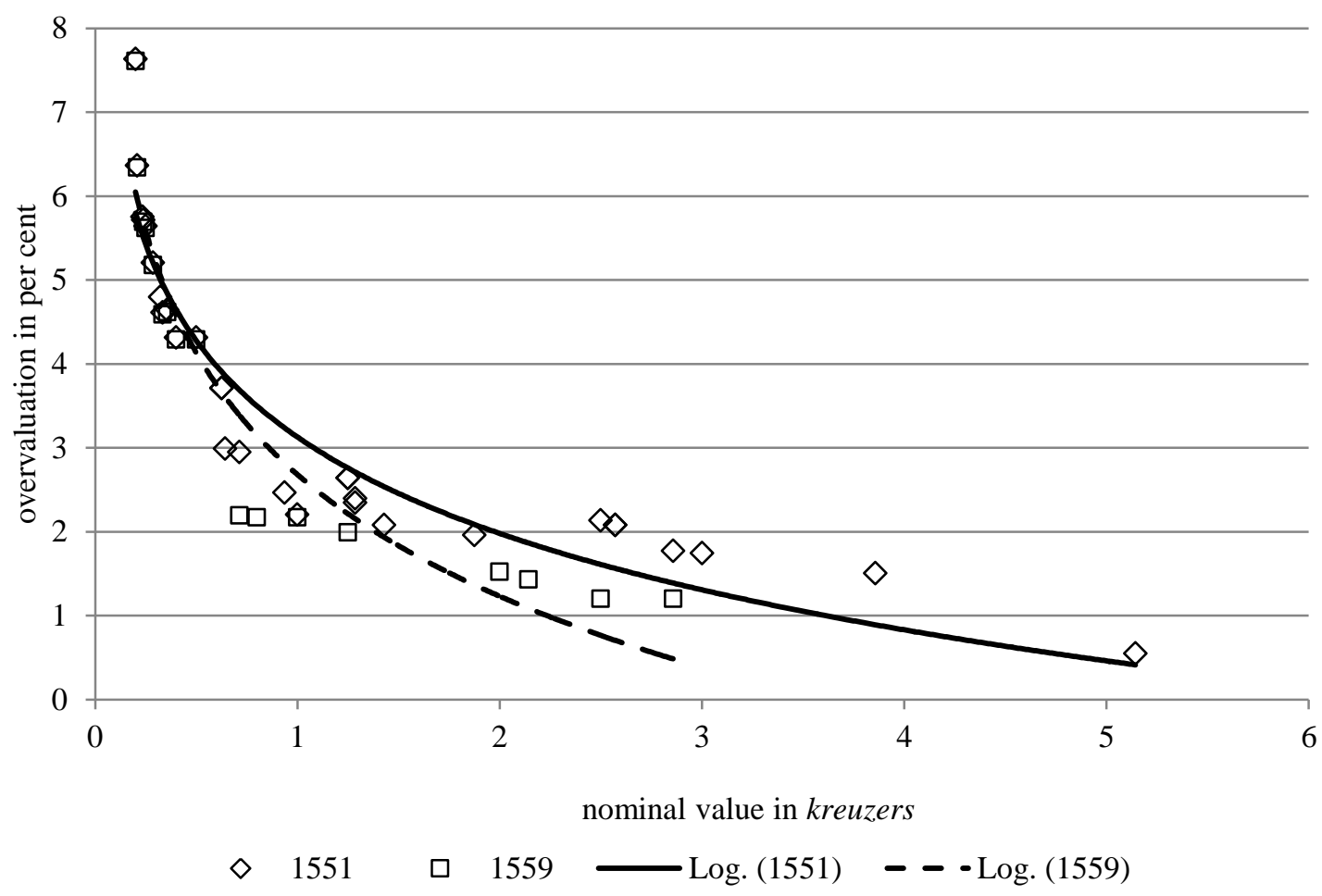

\section{Silver debasements and the price of gold}

As shown above, high information costs not only prevented many authorities from effectively monitoring their agents; they also made it difficult to inform the public about monetary policies and to implement these on the ground. This applied to measures on which debasements depended, too. The most striking instance of this is the manipulation of the official value of coins, which was one the ways a debasement might be carried out. Attempts to do this worked only under very restrictive conditions.

The core issue here was that in the last resort, the value of monetary units was not determined by rulers or governments but by the consumers themselves. This was the case because

4 The graph shows the difference between the mint equivalents of small change (coins below the value of 6 kreuzers in 1551, 5 kreuzers in 1559) and larger full-bodied coins in per cent of the mint equivalent of these larger coins. Both currency laws allowed the common Imperial currency to be supplemented by different types of regional small change. Sources: Volckart (2017a: 346-352), Leeb (1999: 1958-1962). 
normally, the authorities lacked the means to force the public to use money at its official value. If they could have done this, debasements that concerned small change only would have triggered Gresham's law: Consumers would have reacted by holding back the larger, full bodied coins and would have paid goods and services with small change only. However, given that authorities lacked the resources to monitor markets closely enough, the normal consequence of a debasement of small change was that the 'exchange rate' between it and larger denominations of the same currency increased (cf. Redish 2000: 30). This is what happened in Prussia in the years around 1500, where the pennies were debased and the public reacted by using the 15-penny pieces that the mint issued at a rate of 18 pennies (Volckart 1996: 230). Such developments were not necessarily a consequence of debasements, though. In the case of the coins minted according to Charles V's currency law of 1551, it was the excessive supply of small change that drove up the exchange rate of larger coins. Alternatively, a coin might be so popular that consumers were prepared to pay a premium in order to get hold of it. Thus, the Saxon taler that was intended to be a 21-groschens piece began to circulate at 24 , for some time even at 25 groschens in the decades before 1550 (Arnold 1980: 64) - this without any reinforcement of the taler or debasement of groschens, and without anything pointing to an oversupply of the smaller coins. Likewise, the Austrian silver gulden minted since 1521 soon increased from 60 to 64 kreuzers (Schalk 1881: 328). The upshot is that governments were usually incapable of fixing the value of a coin not only in relation to goods and services or to monetary units belonging to other currencies, but relative to other denominations of the same currency, too. This is not to imply that there was an entirely open market where 'exchange rates' were freely negotiated. Even if authorities failed to enforce politically imposed coin values, any attempt to do so would have some effect on supply and demand. Moreover, as shown above, there was no level playing field as the higher social standing of some consumers gave them more bargaining power than others. Still, it is a generally valid conclusion that governments had little influence on the value of coins, which consumers determined in a process of negotiation - skewed though this must have been - among themselves (cf. Rössner 2012: 464 f.).

This applied to gold, too - all the more so as many types of gold coins were used in longdistance trade and therefore outside the region or town ruled by the authority that had issued them. However, even domestically, the official parity between gold and silver proved normally impossible to enforce. For example, in 1468 the city of Lübeck debased its silver by almost 10 per cent, with the bullion content of the double shilling falling from 2.82 to 2.53 
grams (Ropp 1890: 38, 66 f.). The gold content of the Lübeck gulden was left unchanged at 3.51 grams (Jesse 1928: 218). At the same time, Lübeck's council attempted to stabilise the gulden's nominal value at 28 shillings. Consumers did not take heed. On the market, the gulden had been traded at 30 shillings even before the debasement; now it jumped to 32 shillings (Ropp 1890: 34, 41, Jesse 1928: 216, 218). This was typical. Premodern authorities, whether they were urban governments or princes, were generally unable to enforce the circulation of their gold at its nominal par value (Miskimin 1985/89: IX, 149), or to be precise, they were able to do so only if the legal par value conformed to the - in whichever way negotiated - market value. This condition was so restrictive that authorities debasing their silver usually did not concern themselves with adjusting the value of their gold. In other words, many did not even attempt to supply a bimetallic currency where there was a legally fixed ratio between gold and silver coins; rather, they supplied two distinct parallel currencies that were based on different precious metals and whose relative value was floating.

\section{Debasements and counterfeits}

As explained above, there was a third consequence of high information costs which crucially affected debasements: the porousness of currency borders. Fiscal concerns such as those that drove e.g. Albert of Brandenburg to debase his coinage were of course in many cases obvious. However, the literature's frequent focus on this motive obscures the importance of the de facto lack of borders. It was problems resulting from this lack which created incentives to pursue policies that had the same effects as debasements; these, in turn, caused problems that many late medieval and early modern governments tried to address by debasing their own currencies, too.

By the fifteenth century at the latest, merchants had begun to exploit the porousness of borders by engaging in what policy makers called a 'trade in coinage'. A position paper presented at a conference convened by the princes and free cities of the Holy Roman Empire in 1549 in order to discuss Charles V's monetary policies described the phenomenon. It stated that 'masses of batzens [popular South German 4-kreuzers pieces, OV] are exported from the Empire to be melted and re-minted'. Conversely, 'much Italian and French silver money, which matches neither the German money's weight nor its fineness, is imported into Germany; this money is being made of the raw silver and batzens previously exported'. Rhineguldens, i.e. the gold coins most commonly used in fifteenth- and sixteenth-century long-distance trade, were also 'bought up in Germany and exported to Italy where they are 
converted into Italian crowns and then re-imported. This has been turned into a regular trade' (Volckart 2017a: 40 f.). A similar trade flourished within the Empire. Johann Oldecop, a contemporary annalist from North Germany, pointed to the incentives it created for rulers issuing coins. According to Oldecop, in the years around 1550

'many counterfeit talers were issued, in part underweight and in part made of lead, some of copper, some of poor bullion. Moreover, the authorities of the lands where these invalid and false talers were minted struck them with fraudulent legends so that anyone who did not carefully test the talers would believe they were genuine and had been issued by some pious prince or town. [...] Devilry, wickedness and deception were at that time considered a vocation and proper mercantile business practice: Many hucksters and other merchants let coins be minted from coins [...]. Others travelled about, offering their goods throughout the country or in army camps where they bought up talers or gold with counterfeit coins' (Euling 1891: 380).

Oldecop was a cleric and theologian and his moral outrage needs to be taken with a pinch of salt. However, there is no doubt that trade in coinage was widespread. It worked and was profitable for two reasons. First, as suggested by Oldecop, underweight copies often resembled the original coins. 'Replicating other authorities' designs' was considered a common malpractice in premodern coinage (cf. Volckart 2017a: 233, 364). From the perspective of the copyist, this made sense. For example, when Duke Philip the Bold (13631404) of Burgundy began issuing imitations of golden English Nobles in 1388, merchants flocked to the Burgundian mints to sell the English originals: unsurprisingly so, as Philip's nobles contained 7.63 grams of pure gold while those minted in England contained 7.78 grams (Spufford 1963: 129 f., Munro 1972: 43-63). Obviously, the merchants realised that the quality of the Burgundian coins was lower. However, they counted on being able to use them on par with the English originals, either relying on finding transaction partners who did not know the difference or on their superior bargaining power that would allow them to pressure well-informed consumers into accepting Burgundian nobles in place of English ones. The 'war of the nobles' in about 1400 is a prominent example but more than 350 years later, much the same kind of policies were still practiced. In the middle of the eighteenth century, genuine Saxon talers contained 17.48 grams of pure silver, whereas the masses of imitations produced by Frederick II of Prussia (and exported to Saxony) during the SevenYears War held as little as 3.24 grams (Engel 1855: 53, Schrötter 1910: 509). Prussian imitations of Polish coins were equally numerous and equally poor (Koser 1900: 344-351, 
Hoensch 1973: 121 ff.). While here it was the government that was responsible for the decision to produce inferior imitations, this was not necessarily the case. As Burkhard Waldis pointed out in the memorandum quoted above, poorly supervised mint officials would strike underweight coins autonomously, intending to 'attract their neighbours' money that they then remint in their own workshops' (Arbusow 1910: 799).

The examples demonstrate how fluid the transitions between several types of monetary policies were. What Philip the Bold did was no debasement in the strict sense of the word, as he introduced a monetary unit that was new at least within the structure of his own currency. However, given the close similarity between his own nobles and the English ones, it functioned like a debasement, attracting bullion to the Burgundian mints. Frederick II's 'Saxon' talers and 'Polish' coins had a similar effect. However, while the design of Philip the Bold's nobles showed some subtle differences to that of the English coins, which protected him against being accused of counterfeiting, the Prussian coins looked so similar to the originals that they must be considered forgeries, and have been called this by contemporaries and later research (Gumowski 1948). ${ }^{5}$ The examples thus go to show how blurry the line between debasements and counterfeiting was in premodern Europe.

There was a second reason for why the trade in coinage was profitable. This was linked to the use of similar units of account based on distinct actual coins. Again, the process is well attested in the Empire, where a new unit of account that facilitated trade evolved in about 1500. Towards the end of the fifteenth century, many princes and towns had tried to link their local silver currencies to gold by legally fixing their exchange rate with the rhinegulden: For example, 60 Austrian kreuzers, 20 Braunschweig mariengroschens, 21 Saxon zinsgroschens and 32 Brandenburg märkische groschens were declared to be the equivalent of 1 rhinegulden. Initially the ratio was stable: In e.g. Vienna the relative market price of gold and silver as expressed in the exchange rate between rhinegulden and kreuzers remained unchanged between 1500 and 1522 (Schalk 1881: 260 f.). ${ }^{6}$ As a consequence, consumers began to call the sum of 60 kreuzers a gulden even when they did not handle actual gold coins. The same happened in other parts of the Empire where the gold-silver ratio was guineas, too (Anon. (Egid Valentin Felix von Borié) 1761). Frederick depended on British subsidies for about one-third of his expenditure during the Seven-Years War (Koser 1900: 359).

6 Moreover, by the early sixteenth century currency markets were well-integrated so that local goldsilver ratios were fairly close (Chilosi and Volckart 2011: 760). 
unchanged for long enough. It began generally to shift from the 1520 s onward, with the value of gold increasing in many places, but by then the public had become used to treating the gulden as a unit of account whose value was expressed in different quantities of local silver coins. This new unit of account was still the same in many parts of the empire, but it was now divorced of the exchange rate between these silver coins and the actual golden rhineguldens and was maintained even when some princes and towns debased their silver (Volckart 2017a: XXXIII). The result was that by the 1530s, a plethora of silver coins were in circulation whose intrinsic value differed but whose ratio to the gulden of account was still fixed.

Two so-called 'assays' - official metallurgical tests of current coins - show how large the deviations were which this could cause. One was taken in 1533; it was ordered by the council of the city of Augsburg and concerned batzens, the popular 4-kreuzers coins mentioned above, 15 of which were reckoned to be the equivalent of a gulden. Batzens minted by 20 different Upper-German authorities were tested (Thomann von Hagelstein 1692: 72). The other assay was the one carried out in Nuremberg in 1551 in preparation of Charles V's project to create a common Imperial currency. The mint masters gathered for the assay tested a huge variety of coins; those of interest here are the 10 types of mariengroschens (20 of which were a gulden of account) that had been issued by princes and towns in North-Western Germany (Volckart 2017a: 335). Table 1 shows the summary statistics of the two assays.

Table 1: Pure silver content of batzens and mariengroschens, 1533 and 1551 (in grams) ${ }^{7}$

\begin{tabular}{lcc}
\hline & Batzens 1533 & Mariengroschens 1551 \\
\hline $\mathrm{N}$ & 20 & 10 \\
Minimum & 1.551 & 0.744 \\
Maximum & 1.668 & 0.913 \\
Average & 1.601 & 0.825 \\
Standard deviation & 0.032 & 0.058 \\
\hline
\end{tabular}

Despite all batzens and all mariengroschens having the same official values, the designs differed widely so that confusing the issue of one authority with that of another was hardly possible. Hence, merchants engaging in the trade in coinage could not exploit Gresham's Law in the straightforward way that the parallel circulation of the outwardly similar looking English and Burgundian nobles had allowed in about 1400. However, the use of the gulden as a common unit of account still made this possible. Consumers were prepared to accept that 15 
batzens, regardless who had minted them, were one gulden of account and thus interchangeable. Mariengroschens varied more widely than batzens, but the principle was still the same: Merchants could cull a gulden's worth of the types with the highest silver content and sell them to a mint that produced lighter equivalents. If the difference between the bullion contents was large enough to cover the costs of transporting, melting and reminting the coins they would receive more than a gulden's worth of the lighter variant, making a profit in this way. They could do the same even if no coins of the same official value were concerned. For example, from a merchant's perspective selling a gulden's worth of batzens to a mint that produced mariengroschens always made sense if the mariengroschens could be used in a place where batzens were minted. That this happened is attested e.g. from Augsburg in the late $1540 \mathrm{~s} .{ }^{8}$ In fact, the trade in coinage was so common that many mints would have been forced to close without it. According to Schüttenhelm's (1984: 165) estimate, more than half of the bullion used by South German mints in the first half of the sixteenth century was not bought from mines or merchants but consisted of melted foreign coins. Given the use of a common unit of account, reminting such coins amounted to a policy that for practical purposes was no better than a debasement.

The consequence of all these varieties of the trade in coinage was that in the place of origin of the heavier coins, those with a proportionally lesser content of bullion would appear in circulation. This is what happened, for example, in England after Philip the Bold had begun issuing his imitation nobles. Only four years later, in 1392, the English government legislated against

'gold money of the coinage of Flanders and Brabant [...] as by report of great number of credible persons it is newly come to the King's ears that natives and aliens are bringing into the realm divers such gold money much resembling English money but of less weight and value therewith buying and selling as if it were of the English coinage, which it is not, and making other payments to the deception and damage of the King and people' (Maxwell Lyte 1925: 110).

As a result of such developments, the supply of specie to the mints producing heavier coins dried up, and with it the revenues from the seignorage. More serious, from an economic point 
of view, was the effect on transaction costs. The more different types of coins circulated at par despite their intrinsic value being different, the less sure could the public be that the money they handled matched their expectations. In consequence, more consumers would feel the need to check the weight and bullion content of their coins, and if they were unable to do that, would be inclined to reject money or not to engage in transactions that would, if money had been stable and known, have been mutually advantageous. The trade in coinage thus did not only harm the revenues of authorities. It was impeded the functioning of the market with all consequences this had for the division of labour, specialisation and factor allocation. Short of creating a common currency, the only feasible solution was debasing the domestic coinage so far that its bullion content matched or undercut that of the foreign money that had entered the market. Chilosi and Volckart (2017: 119 ff.) have shown statistically that urban governments took this factor significantly more often into account when deciding about debasements than princes. Thus, while princes tended to debase for fiscal reasons, thereby disturbing market transactions, towns debased more readily in order to drive out underweight foreign money. In this way, they reduced insecurity and transaction costs and helped their markets to function

\section{Conclusion}

The present chapter analyses how late medieval and early modern debasements were affected by the wider economic and social conditions of the time. It explains that debasements were possible because merchants selling bullion to a mint were able to exploit two conditions: Either an informational asymmetry existed between them and poorly informed consumers, who did not realise that the coins they accepted had been debased, or the merchants' social standing meant they were powerful enough to force even well-informed consumers to accept debased money.

The core hypothesis of the chapter is that in most of premodern Europe debasements were far 'messier' measures than much of the literature, which focuses on conditions in parts of Western Europe, realises. That high information costs allowed rulers debasing their coinage and merchants selling them bullion to 'fool' poorly informed consumers was only one side of the medal. The same information costs not only prevented the effective implementation of monetary policies but often created conditions which allowed or even motivated debasements. First, high information costs prevented the effective monitoring of agents employed to carry out governmental decisions. Even where rulers had not farmed out their 
mints, officials therefore often enjoyed a remarkable degree of autonomy. As the decision of which type of coin to mint was usually up to them, they tended to focus on minting those coins where their profit was highest. Moreover, there is evidence that on occasion out-ofcontrol mint officials debased the coinage without referring to the authority that employed them. Thus, the flood of debased small change that undermined the common currency of the Holy Roman Empire at the end of the sixteenth and the beginning of the seventeenth century was issued by mints operating without supervision by the rulers officially responsible for them.

Second, high costs of information impeded attempts by political authorities to enforce regulations. This affected regulations concerning the value of coins, too. Research has so far often argued that in order to prevent the export of gold, governments debasing silver were forced to debase their gold coins, too, and that they normally did this not by reducing the bullion content, but rather by increasing the nominal value of gold coins. In fact, such measures were effective only under very restrictive conditions. As a rule, premodern governments were incapable of enforcing the circulation of gold at its nominal par value. To be precise, this was possible only if the rate they set for their gold happened to conform to the market rate. The reason was that it was usually the market that determined the value of monetary units: Purchasing power, exchange rates with coins belonging to other currencies and the rates at which other coins from the same currency circulated were all open to negotiation between consumers. In the context of the supply of gold and silver coins, this implied that few premodern governments were able successfully to manage bimetallic currencies. Rather, most issued two distinct currencies based on different metals and circulating in parallel.

The final issue analysed is the effect of information costs on attempts to create closed areas where the domestic currency enjoyed a monopoly, with costs being usually so high that this proved impossible. Normally borders were porous to the flow of coins, the more so as by the late Middle Ages a regular trade in coinage had developed. In part, this trade exploited the usually intentional - similarity between coins minted by different rulers, buying those whose bullion content was higher and selling them to a mint that produced inferior copies. The ruler who issued these copies, strictly speaking, did not debase his coinage as long as the copies were new units within the structure of his own currency, but his measure had still the same effect as a debasement, allowing him to increase his mint output and seignorage. Instances like these therefore show how thin the line between debasement and counterfeiting was. 
Occasionally, the trade in coinage also exploited the use of the same unit of account in different currencies. The effect was the same, with inferior coins replacing the better ones and allowing the authority issuing them to increase its seignorage. Also, in both cases the increasing circulation of 'bad' foreign coins that drove 'good' domestic ones out of circulation created strong incentives for the authority suffering from this influx to debase its own money, too. Debasements were therefore by no means exclusively fiscally motivated; they could just as well be defensive.

In sum, a debasement was anything but the orderly process envisaged by much of the prior research, where a ruler decided to debase his coinage, set the new mint price and patiently waited for members of the public to voluntarily supply his mint with bullion. Rather, debasements could be measures autonomously taken by poorly supervised officials. Also, mints acquired bullion in any way they could. In particular in cases of fiscally motivated debasements, confiscated gold or silver and re-minted foreign subsidies became important sources of supply. Generally, coins minted by other authorities served as raw material if they looked similar but had a higher intrinsic value or if the public used them in conjunction with the same unit of account. Moreover, as a rule measures on which specific types of debasements - e.g. increasing a coin's legal value - depended proved impossible to enforce. Still, as the examples of the Dauphin in the early fifteenth and Frederick II of Prussia in the mid-sixteenth century show, where a ruler aimed at increasing his revenues, debasing the coinage might be a hugely successful way to achieve this end.

\section{References}

Primary Sources

Anon. (Egid Valentin Felix von Borié). 1761. Staats-Betrachtungen über gegenwärtigen Preußischen Krieg in Teutschland, in wiefern solcher das allgemeine Europäische, vornehmlich aber das besondere Teutsche Interesse betrift: mit untermischten Völker-rechtlichen Bemerkungen. Wien: Kaliwoda.

Arbusow, Leonid, ed. 1910. Akten und Recesse der livländischen Ständetage. Vol. 3 (1494 - 1535). Riga: Deubner.

Euling, Karl, ed. 1891. Chronik des Johan Oldecop, Bibliothek des Litterarischen Vereins in Stuttgart CXC. Tübingen: Litterarischer Verein in Stuttgart.

Fachs, Modestin. 1678. Probier-Büchlein. Leipzig: Christian Scholvien.

Helfferich, Karl Theodor, ed. 1900. Ludwig Bamberger: Ausgewählte Reden und Aufsätze über Geldund Bankwesen. Berlin: Guttentag.

Klempin, R. 1859. Diplomatische Beiträge zur Geschichte Pommerns aus der Zeit Bogislafs X. Berlin: A. Bath.

Leeb, Josef. 1999. "Der Kurfürstentag zu Frankfurt 1558 und der Reichstag zu Augsburg 1559." In Deutsche Reichstagsakten: Reichsversammlungen 1556-1662, ed Historische Kommission bei der Bayerischen Akademie der Wissenschaften. Göttingen: Vandenhoeck \& Ruprecht. 
Maxwell Lyte, Henry Churchill, ed. 1925. Calendar of Close Rolls, Richard II. Vol. 5, 1392-1396. London: His Majesty's Stationery Office.

Meckelburg, Friedrich A., ed. 1865. Die Königsberger Chroniken aus der Zeit des Herzogs Albrecht; darin die Chronik des Johannes Freiberg. Königsberg: W. Koch.

Meyer, Sophie. 1912. "Die Beler-Platnersche Chronik." Altpreußische Monatsschrift 49: 343-415, 593-663.

Ropp, Goswin Frhr. von der, ed. 1890. Hanserecesse von 1431-1476. Vol. 6 (2. Abt.). Leipzig: Duncker \& Humblot.

Thomann von Hagelstein, David. 1692. Der Röm. Kayserl. Majestät Deß Heil. Röm. Reichs Geistund Weltlicher Chur-Fürsten, Fürsten und Ständen Acta Publica Monetaria Schrifftliche Handlungen, Constitutiones, Bedencken und Vorschläge, Die Anordnung, Reformation und Verbesserung Deß Müntz-Wesens in Teutschland betreffende. Augsburg: Kroniger \& Göbels Erben.

Volckart, Oliver, ed. 2017a. Eine Währung für das Reich: Die Akten der Münztage zu Speyer 1549 und 1557. Edited by Historische Kommission bei der Bayerischen Akademie der Wissenschaften durch Gerhard Fouquet, Deutsche Handelsakten des Mittelalters und der Neuzeit XXIII. Stuttgart: Steiner.

Secondary Sources

Arnold, Paul. 1980. "Die sächsische Talerwährung von 1500 bis 1763." Schweizerische Numismatische Rundschau 59: 50-94.

Behringer, Wolfgang. 2005. ""Von der Gutenberg-Galaxis zur Taxis-Galaxis". Die Kommunikationsrevolution: Ein Konzept zum besseren Verständnis der Frühen Neuzeit." Historische Zeitschrift. Beihefte 41: 39-54.

Blanchet, Jules-Adrien, and Adolphe Dieudonné. 1916. Manuel de numismatique Française. Vol. 2. Paris: Picard.

Buringh, Eltjo, and Jan Luiten van Zanden. 2009. "Charting the "Rise of the West": Manuscripts and Printed Books in Europe, A Long-Term Perspective from the Sixth through Eighteenth Centuries." Journal of Economic History 69: 409-445.

Chilosi, David, and Oliver Volckart. 2011. "Money, States and Empire: Financial Integration and Institutional Change in Central Europe, 1400-1520." Journal of Economic History 71 (3): 762-791.

Chilosi, David, and Oliver Volckart. 2017. "Good or Bad money? Debasements, Society and the State in the Late Middle Ages." In Money and Its Use in Medieval Europe Three Decades On: Essays in Honour of Professor Peter Spufford, edited by Martin Allen, 111-128. London: The Royal Numismatic Society.

Daubney, Adam. 2009. "The Circulation and Prohibition of Venetian Soldini in Late Medieval England." British Numismatic Journal 79: 186-198.

Denecke, Dietrich. 1990. "Straße und Weg als Lebensraum und Vermittler zwischen entfernten Orten." In Mensch und Umwelt im Mittelalter, edited by Bernd Herrmann, 207-223. Frankfurt: Fischer.

Dipper, Christof. 1991. Deutsche Geschichte 1648-1789, Neue historische Bibliothek 253. Frankfurt: Suhrkamp.

Engel, Ernst. 1855. "Die Geldprägungen nach dem Leipziger Münzfuße, dem Conventionsfuße und dem 14-Thalerfuße in dem Churfürstenthume und dem Königreiche Sachsen." Zeitschrift des Statistischen Büreaus des Königl. Sächs. Ministeriums des Innern 4: 49-64.

Engelsing, Rolf. 1973. Analphabetentum und Lektüre: Zur Sozialgeschichte des Lesens in Deutschland zwischen feudaler und industrieller Gesellschaft. Stuttgart: Metzler.

Glassman, Debra, and Angela Redish. 1985. "New Estimates of the Money Stock in France, 14931680." Journal of Economic History 45 (1): 31-46.

Gould, John D. 1970. The Great Debasement: Currency and the Economy in Mid-Tudor England Oxford: Clarendon Press.

Groebner, Valentin. 1993. Ökonomie ohne Haus: Zum Wirtschaften armer Leute in Nürnberg am Ende des 15. Jahrhunderts. Göttingen: Vandenhoeck \& Ruprecht. 
Gumowski, Marian. 1948. Fatszerstwa monetarne Fryderyka II. Poznań: Instytut Zachodni.

Hettling, Manfred. 2015. "Bürger/Bürgerlichkeit." In Handbuch Europäische Aufklärung: Begriffe Konzepte - Wirkung, edited by Heinz Thoma, 123-131. Stuttgart, Weimar: J. B. Metzler.

Hoensch, Jörg K. 1973. "Friedrichs II. Währungsmanipulationen im Siebenjährigen Krieg und ihre Auswirkungen auf die polnische Münzreform von 1765/66." Jahrbuch für die Geschichte Mittel- und Ostdeutschlands 22: 110-173.

Houston, Rab. 2014. Literacy in Early Modern Europe: Culture and Education 1500-1800. London, New York: Taylor \& Francis.

Jesse, Wilhelm. 1928. Der Wendische Münzverein, Quellen und Darstellungen zur hansischen Geschichte NF 6. Lübeck: Hansischer Geschichtsverein.

Koser, Reinhold. 1900. "Die preußischen Finanzen im siebenjährigen Kriege." Forschungen zur brandenburgischen und preußischen Geschichte 13: 153-217, 329-375.

Laube, Adolf. 1976. Studien über den erzgebirgischen Silberbergbau von 1470 bis 1546: Seine Geschichte, seine Produktionsverhältnisse, seine Bedeutung für die gesellschaftlichen Veränderungen und Klassenkämpfe in Sachsen am Beginn der Übergangsepoche vom Feudalismus zum Kapitalismus. Edited by G. Heitz, E. Müller-Mertens, B. Töpfer and E. Werner. 2 ed, Forschungen zur Mittelalterlichen Geschichte 22. Berlin: Akademie-Verlag.

Metcalf, D.M., and J.M. Merrick. 1967. "Studies in the Composition of Early Medieval Coins." The Numismatic Chronicle 7: 167-181.

Miskimin, Harry A. 1985/89. "The Enforcement of Gresham's Law." In Cash, Credit and Crisis in Europe, 1300-1600, edited by Harry Miskimin, IX, 147-161. London: Variorum Reprints.

Münch, Paul. 1996. Lebensformen in der Frühen Neuzeit 1500 bis 1800. Frankfurt, Berlin: Ullstein.

Munro, John H. 1972. Wool, Cloth, and Gold: The Struggle for Bullion in Anglo-Burgundian Trade, 1340-1478. Brussels, Toronto: University of Toronto Press.

Munro, John H. 2015. "The Technology and Economics of Coinage Debasements in Medieval and Early Modern Europe: with Special Reference to the Low Countries and England." In Money in the Pre-Industrial World: Bullion, Debasements and Coin Substitutes, edited by John H. Munro, 15-32. Abingdon: Routledge.

Prestwich, Michael. 1979. "Early Fourteenth-Century Exchange Rates." Economic History Review XXXII (4): 470-482.

Redish, Angela. 2000. Bimetallism: An Economic and Historical Analysis. Cambridge, New York: Cambridge University Press.

Rolnick, Arthur J., Francois R. Velde, and Warren E. Weber. 1996. "The Debasement Puzzle: An Essay on Medieval Monetary History." Journal of Economic History 56 (4): 789-808.

Rössner, Philipp Robinson. 2012. Deflation - Devaluation - Rebellion: Geld im Zeitalter der Reformation. Edited by Günter Schulz, Jörg Baten, Markus A. Denzel and Gerhard Fouquet, Vierteljahrschrift für Sozial- und Wirtschaftsgeschichte, Beiheft 219. Stuttgart: Steiner.

Rössner, Philipp Robinson. 2014. "Monetary Instability, Lack of Integration, and the Curse of a Commodity Money Standard: The German Lands, c.1400-1900 A.D." Credit and Capital Markets - Kredit und Kapital 47 (2): 297-340. doi: 10.3790/ccm.47.2.297.

Sargent, Thomas J., and François R. Velde. 2002. The Big Problem of Small Change. Edited by Joel Mokyr, The Princeton Economic History of the World. Princeton, Oxford: Princeton University Press.

Schalk, Carl. 1881. "Der Wiener Münzverkehr im 16. Jahrhundert." Numismatische Zeitschrift 13: 243-329.

Schneider, Konrad. 1995. "Heckenmünze." In Von Akte bis Zoll: Ein historisches Lexikon des Geldes, edited by Michael North, 156-157. München: Beck.

Schrötter, Friedrich Frhr. von. 1910. Das Preussische Münzwesen im 18. Jahrhundert: Münzgeschichtlicher Teil. Vol. 3: Das Geld des siebenjährigen Krieges und die Münzreform nach dem Frieden: 1755 - 1765. Berlin: Parey.

Schüttenhelm, Joachim. 1984. "Zur Münzprägung und Silberversorgung süddeutscher Münzstätten im frühen 16. Jahrhundert." In Der Anschnitt: Zeischrift für Kunst und Kultur im Bergbau. Beiheft 2: Montanwirtschaft Mitteleuropas vom 12. bis 17. Jahrhundert. Stand, Wege und Aufgaben der Forschung, edited by Werner Kroker, 159-169. Bochum: Deutsches BergbauMuseum. 
Scott, Hamish M. 2015. The Oxford Handbook of Early Modern European History, 1350-1750. Vol. 1: Peoples and Place. Oxford: Oxford University Press.

Sprenger, Bernd. 2002. Das Geld der Deutschen: Geldgeschichte Deutschlands von den Anfängen bis zur Gegenwart. 3 ed. Paderborn, München, Wien, Zürich: Schöningh.

Spufford, Peter. 1963. "Continental Coins in Late Medieval England." British Numismatic Journal 32: $127-139$.

Spufford, Peter. 1988. "Mint Organisation in Late Medieval Europe." In Later Medieval Mints: Organisation, Administration and Techniques. The Eighth Oxford Symposium on Coinage and Monetary History, edited by Peter Spufford and Nicholas J. Mayhew, 7-29. Oxford: B.A.R. Publications.

Sussman, Nathan. 1993. "Debasements, Royal Revenues, and Inflation in France during the Hundred Years' War, 1415-1422." Journal of Economic History 53 (1): 44-70.

van Zanden, Jan Luiten, and Maarten Prak. 2006. "Towards an Economic Interpretation of Citizenship: The Dutch Republic Between Medieval Communes and Modern Nation-States." European Review of Economic History 10 (2): 111-145.

Volckart, Oliver. 1996. Die Münzpolitik im Deutschordensland und Herzogtum Preußen von 1370 bis 1550. Wiesbaden: Harrassowitz.

Volckart, Oliver. 2017b. "Power Politics and Princely Debts: Why Germany's Common Currency Failed, 1549-1556." Economic History Review 70 (3): 758-778.

Wuttke, Robert. 1897. "Die Probationsregister des Obersächsischen Kreises." Numismatische Zeitschrift 29: 237-302. 